\title{
Genetic and morphological differentiation in the Sakura shrimp (Sergia lucens) between Japanese and Taiwanese populations
}

\author{
Hideyuki Imai ${ }^{1,4}$, Yukio Hanamura ${ }^{2}$, Jin-Hua Cheng ${ }^{3}$ \\ ${ }^{1}$ Laboratory of Marine Biology and Coral Reef Studies, Faculty of Science, University of the Ryukyus, Nishihara, \\ Okinawa 903-0213, Japan \\ ${ }^{2}$ National Research Institute of Fisheries Science, Fisheries Research Agency, Kanazawa-ku, Yokohama 236-8648, \\ Japan \\ ${ }^{3}$ Tungkang Biotechnology Research Center, Taiwan Fisheries Research Institute, Pingtung 928, Taiwan \\ ${ }^{4}$ E-mail:imai@sci.u-ryukyu.ac.jp
}

Keywords: gene flow, genetic diversification, morphology, stock identification

\begin{abstract}
The Sakura shrimp Sergia lucens is a remarkable meso-pelagic crustacean species, which is harvested for human consumption in restricted geographical areas of Taiwan and Japan in the northwestern Pacific. Nucleotide sequence analysis of the mitochondrial DNA control region was conducted to investigate the levels of genetic variability and differentiation between Japanese and Taiwanese populations of $S$. lucens. The latter half of the control region, which contained 589 nucleotide sites, was sequenced using DNA extracted from 178 individuals from the two geographical regions. Analyses yielded 162 haplotypes, and the amount of genetic variability within the populations as shown by the levels of haplotype and nucleotide diversity revealed that the two populations included in this study have higher levels of diversity than intraspecific variation previously reported in other crustaceans. Our AMOVA and pairwise Fst results indicated the existence of significant genetic differences between the Japanese and Taiwanese populations. Morphological analyses also revealed minor but notable differences between the two groups. These findings suggest that postulated gene flow of S. lucens is unlikely to occur across the isolated Japanese and Taiwanese populations, and that each population completes their life history in a restricted geographical area.
\end{abstract}

\section{Contents}

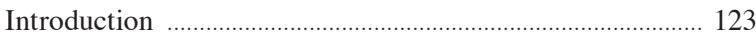

Material and methods ............................................................. 124

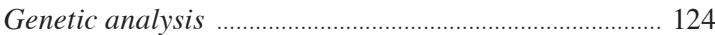

Morphological analysis .................................................... 125

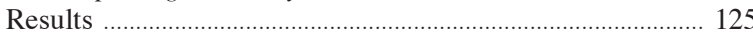

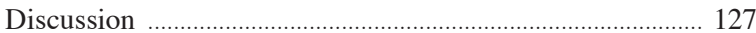

Acknowledgements .................................................................. 128

References ………........................................................................ 128

\section{Introduction}

The genetic population structures of aquatic animals are often correlated with varying levels of dispersal in their species, which are closely associated with swimming ability, type/duration of larval stages, or water currents. In the north Pacific region, from tropical to temperate areas, the Kuroshio Current plays an important role in the distribution of marine organisms. For example, the Japanese eel Anguilla japonica Temmink and Schlegel, 1847 does not show any genetic differentiation among Taiwanese, Chinese and Japanese populations (Taniguchi and Numachi, 1978; Minegishi et al., 2012). On the other hand, some species, such as the Bowed fiddler crab Uca arcuata (De Haan, 1833), Bigfin reef squid Sepioteuthis spp. and Golden rabbitfish Siganus guttatus (Bloch, 1787), show genetic differences among populations (Aoki et al., 2008a, b; Imai and Aoki, 2012; Iwamoto et al., 2012).

The Sakura shrimp Sergia lucens (Hansen, 1922) is a commercially important species that is found in the same Kuroshio region. In the past, based on limited numbers of specimens, genetic differences were reported between Japanese and Taiwanese populations (Omori et al., 1988), despite the two populations supposedly being connected by the Kuroshio Current. Recently, the number of Sakura shrimp caught in Japan has decreased. It is important to understand this species' population structure for appropriate resource management.

Further compounding potential management problems of this species, the species name for the Sakura 
shrimp has not yet been definitively decided. Article 15.1 of the International Code of Zoological Nomenclature (ICZN, 2000; see also Article 11.5.1 concerning "conditional proposals" made before 1961) gives priority to the designation Sergia kishinouyei (Nakazawa and Terao, 1915) over S.lucens, although the latter name has been popularly used by researchers since Gordon (1935), who provided a detailed account of the species (cf. Omori, 1969). Sergestes phosphoreus Kishinouye, 1928 has also been used to refer to the Sakura shrimp, but the validity of this name is questioned (see Vereshchaka, 2000). To avoid taxonomic confusion, herein we use S. lucens until the nomenclature issues of the Sakura shrimp are formally resolved.

Sergia lucens is found from Suruga Bay, Sagami Bay, and the mouth of Tokyo Bay in Japan, and the coastal waters of Tungkang as well as off the east coast of Taiwan (Omori, 1969, 1995; Holthuis, 1980; Omori et al., 1988; Isshiki and Tajima, 1992; Lee et al., 1996). Furthermore, Vereshchaka (2000) recorded this species from off Borneo and New Guinea. This shrimp has been commercially exploited in Suruga Bay and Tungkang, where the annual yields average around 2,000 and 100 tons, respectively (Omori, 1989; Fukui et al., 2004). Several biological aspects of this shrimp, including the spawning activity, egg abundances, larval development, swimming behaviour, and population size fluctuation, have been reported in Suruga Bay (Huzita, 1959; Kosaka et al., 1969; Omori, 1971; Omori and Ohta, 1981; Tsukui, 1987; Bishop et al., 1989; Muranaka and Jo, 1990; Hirai et al., 1992; Omori and Seino, 1993; Isshiki, 1996). In fact, more than 200 research articles, most of them in Japanese, dealing with this shrimp have been published over the last century (Kubota et al., 1995). Omori et al. (1988) conducted a comparative taxonomic study on individuals collected from Suruga Bay and Tungkang waters. These authors did not find morphological differences discriminating the two populations, suggesting that they could be a single species, although they observed differences in spawning season and isoelectrophoretic patterns of water-soluble proteins. However, as this study examined only five individuals per population, no definitive conclusions could be reached in this study. Since this study, no further information regarding the population structure of S. lucens has become available.

Genetic markers such as the mitochondrial DNA control region sequence have been shown to be effective in identifying population structures, and therefore genetic data can contribute to resource management and conservation. As the validity of the research results of Omori et al. (1988) are under question, in this study, the mitochondrial DNA of $S$. lucens collected from the Japanese and Taiwanese coastal waters were analyzed together with comparative morphology to more clearly understand the population structure of this commercially important species.

\section{Material and methods}

\section{Genetic analysis}

Samples were obtained by trawl fishing at three locations in Japan and Taiwan, which represent the main fishing grounds of S. lucens (Fig. 1). In total, 178 specimens were examined for sequence analysis of mitochondrial control region: 70 from Suruga Bay $\left(35^{\circ} 06^{\prime} \mathrm{N}\right.$, $\left.138^{\circ} 38^{\prime} \mathrm{E}\right)$ (collected in 1999), 61 from Tungkang $\left(22^{\circ} 20^{\prime} \mathrm{N}, 120^{\circ} 20^{\prime} \mathrm{E}\right)$ and 47 from Gueishan Island waters $\left(24^{\circ} 51^{\prime} \mathrm{N}, 121^{\circ} 55^{\prime} \mathrm{E}\right)$, Taiwan (collected in 2003 and 2010). All samples were stored at $-40^{\circ} \mathrm{C}$ until use.

Total crude DNA was extracted from the pereopod muscle of the frozen specimens using proteinase $\mathrm{K}$, phenol-chloroform, and TNES-8 $\mathrm{M}$ urea buffer (Imai et al., 2004). The mitochondrial (mt) DNA control region was then amplified by polymerase chain reaction (PCR) using the designed primers shrimp-slCR-f

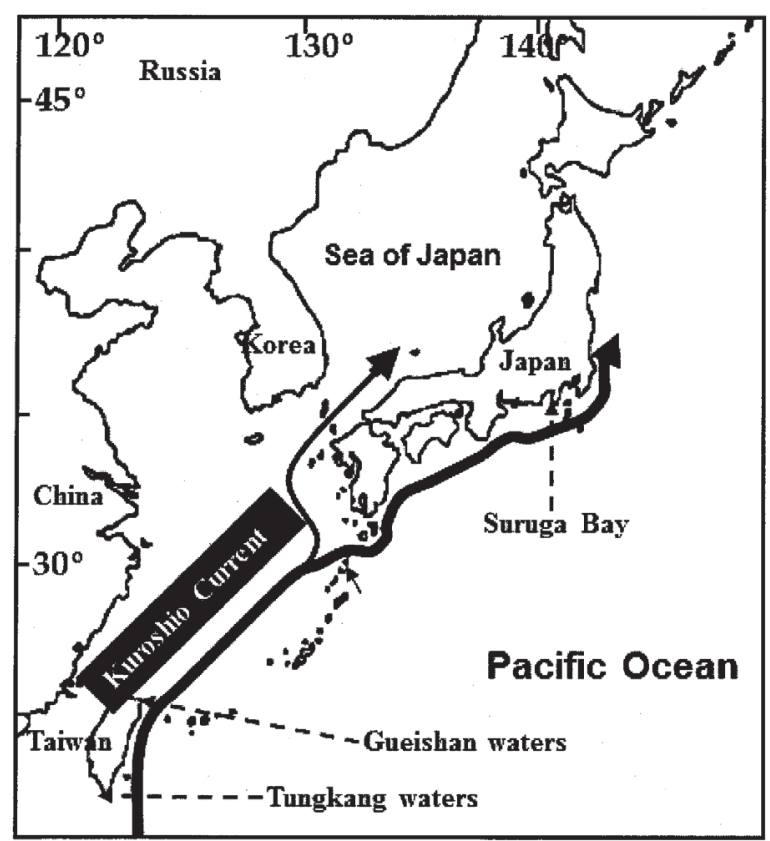

Fig. 1. Sampling sites of Sergia lucens in Japan and Taiwan. 
(5'-GAAATAGTAAACTGTAAGTT-3') and sakuratRNA (5'-TCTATCCTATCAAGATAGCCC-3'). All reactions were carried out in a $50 \mu 1$ total volume containing $1 \mu \mathrm{l}$ of total crude DNA, $25 \mathrm{pM}$ each primer, $2.5 \mathrm{U}$ of ExTaq $^{\mathrm{TM}}$ DNA polymerase (Takara Bio), $5 \mu \mathrm{l}$ of each dNTP, $1 \times$ buffer, and $\mathrm{dH}_{2} \mathrm{O}$. A GeneAmp 9700 thermal cycler (Applied Biosystems) was used with the following parameters: $94^{\circ} \mathrm{C}(60 \mathrm{~s})$ followed by 30 cycles of denaturation at $94.5^{\circ} \mathrm{C}(30 \mathrm{~s})$, annealing at $40.5^{\circ} \mathrm{C}(30 \mathrm{~s})$, and extension at $72^{\circ} \mathrm{C}(60 \mathrm{~s}) . \mathrm{PCR}$ products were purified with Exo-Sap-IT (Usb) and cycle-sequenced using a BigDye Terminator Kit and an ABI 3700 genetic analyzer (Applied Biosystems). The sequences obtained in this research were deposited in the DNA Data Bank of Japan (DDBJ) under Accession Numbers AB846666 to AB846827.

All sequences were initially aligned using ClustalX ver.1.83.1 (Thompson et al., 1997). A median-joining network of haplotypes was constructed using the Network ver. 4.6.1.1 (Bandelt et al., 1999) including all individuals. All calculations [haplotype diversity ( $h$; Nei, 1987), nucleotide diversity ( $\pi$; Tajima, 1983), Fst value and 10,000 times Fst permutation test (Reynolds et al., 1983), an exact test based on 10,000 steps in a Markov chain (Raymond and Rousset, 1995), and the analysis of the molecular variance (AMOVA) (Excoffier et al., 1992) were processed with Arlequin (Excoffier et al., 2005). A sequential Bonferroni test (Rice, 1989) was used to correct multiple tests of the hypothesis, for which the pairwise $F s t$ statistics did not differ from zero. Gene flow $\left(N_{e} m\right)$ was estimated using the relationship $N_{e} m=[(1 / F s t)-1] / 2$ (Hudson et al., 1992). To investigate the population history of S. lucens, a mismatch distribution based on pairwise differences in the mtDNA control region sequences was conducted. In addition, to check for deviations from neutrality, two different $D$ tests (Tajima, 1989; Fu and Li, 1993) were performed using Arlequin.

\section{Morphological analysis}

Thirty-seven specimens of both sexes (8.4-10.4 $\mathrm{mm}$ in carapace length) from the two aforementioned sites in Taiwan (Feb. 2003; July 2010) and 18 specimens (10.0$13.0 \mathrm{~mm}$ ) from Suruga Bay (May 2003) were used for the examination of a relative distance of the photophores on the antennal scale (Fig. 2). The measurements were made using an ocular-micrometer mounted on a bi-ocular microscope. In addition, the structure of the petasma was examined for male specimens (16 individuals from Japan and 42 from Taiwan).

\section{Results}

In total, 589 base pairs (bp) from the control region were sequenced for 178 individuals from the three sampling locations. One hundred and sixty-two haplotypes and 149 variable sites were identified (On-line Supplementary Material, Table S1), and nearly all of the sequenced individuals had a unique haplotype (60 haplotypes from Suruga Bay, 40 haplotypes from Gueishan and 59 haplotypes from Tungkang). However, shared haplotypes were detected in four cases: haplotype 1, seven individuals from Suruga Bay and two from Gueishan; haplotype 2, one from Suruga Bay, three from Gueishan and one from Tungkang; haplotype 92, one from Suruga Bay and one from Gueishan and haplotype 122, one from Gueishan and one from Tungkang. Relationships between haplotypes were represented on a network tree, which did not show any geographical structuring (Fig. 3).

The haplotype and nucleotide diversities of the three geographical groups ranged from 0.991 to 1.000 and from $1.083 \%$ to $1.131 \%$, respectively (Table 1 ). AMOVA in the three populations also showed a significant $\Phi$ st value of $0.0126(P<0.001)$, indicating significant heterogeneity in at least one of the pairwise comparisons. The pairwise $F s t$ value ranged from 0.0179 to 0.0205 , differing significantly between Japan and Taiwan $(P<$ $0.001)$; however, the values between Gueishan and Tungkang indicated no significant genetic differences. Significant population subdivisions were detected between the Japanese and Taiwanese groups (Suruga Bay vs. Gueishan, and Suruga Bay vs. Tungkang; $P<0.05$, Bonferroni adjustment), while the $N_{e} m$ value between pairwise comparisons was 22.96 (Suruga Bay vs. Gueishan + Tungkang waters). Tajima's $D$ and Fu and Li's $D$ tests were also performed to determine neutrality. Significant negative values were obtained from all sampling sites by both tests (Table 1). The distribution of the pairwise number of differences in the control region haplotypes fits an expansion model, with a smooth wave predicted for each location that had undergone a demographic expansion (Fig. 4). The isolation time between the Japanese and Taiwanese populations was estimated to be 305,000 years, based on the observed nucleotide divergence between them and a mutation rate of $19 \%$ / MY, taken from the mtDNA control region of penaeid shrimps (McMillen-Jackson and Bert, 2003).

To support the differences observed in genetic analyses, some morphological features of S. lucens collected from Japan and Taiwan were examined (Fig. 5). These analyses showed that the relative distance of the three 


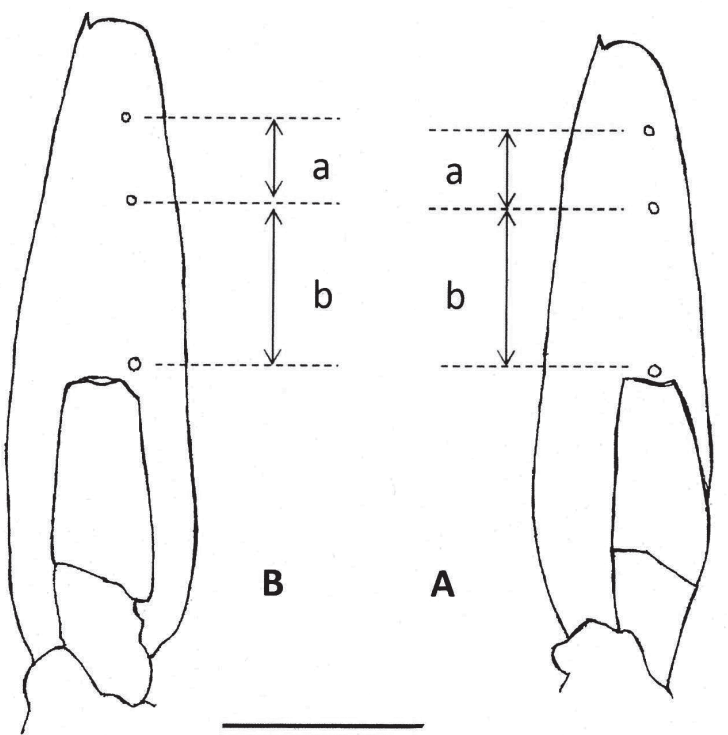

Fig. 2. Antennal scale of Sergia lucens and measurement of photophore distance: male $10.3 \mathrm{~mm}$ in carapace length from Suruga Bay, Japan (A) and male $10.3 \mathrm{~mm}$ from off Gueishan, Taiwan (B).
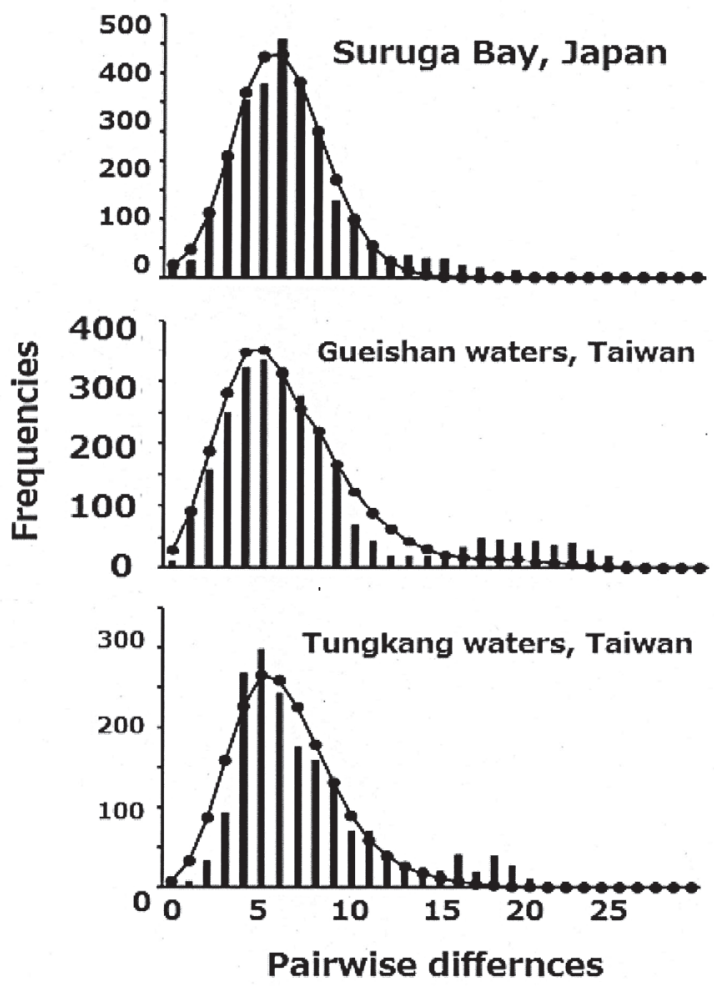

Fig. 4. Observed pairwise differences (bars) and the expected mismatch distributions under the sudden expansion model (line) of haplotypes detected in the Japanese and Taiwanese populations of Sergia lucens.

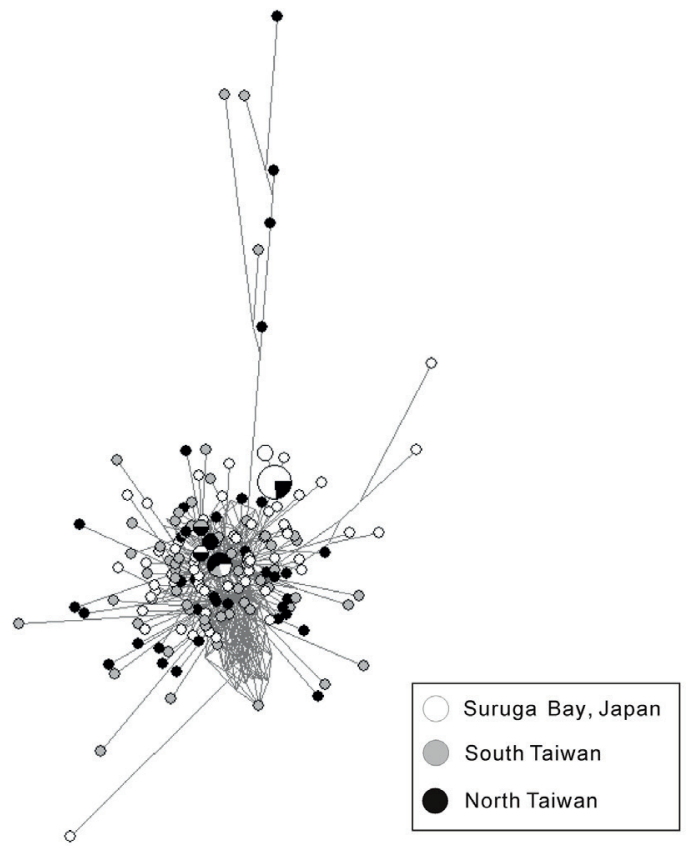

Fig. 3. Haplotype network for 162 haplotypes of Sergia lucens. White, dark and black circles indicated haplotypes among localities. The size of the circles is proportional to the haplotype frequencies. Lengths of the line showed relative to the number of mutations between haplotypes.

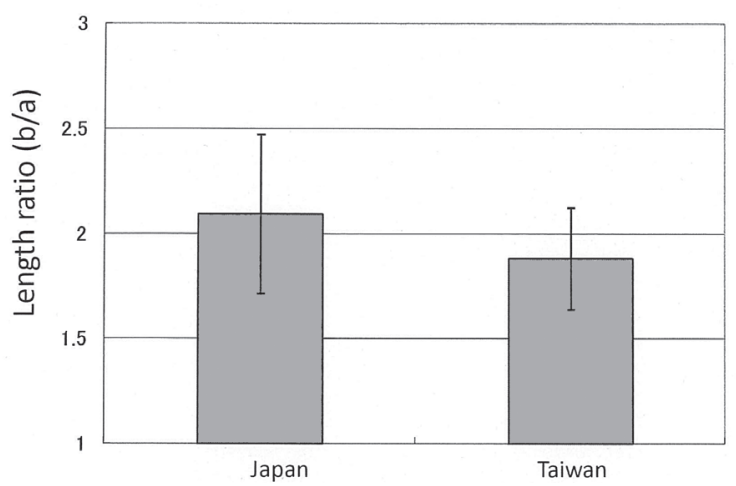

Fig. 5. Comparison in relative distance between the photophores on the antennal scale of Sergia lucens in specimens collected from Japanese and Taiwanese waters.

photophores on the antennal scale differed significantly between the two populations ( $t$-test $=2.414, p<0.05)$, with the Japanese specimens having a mid-photophore placed more posteriorly than the Taiwanese ones.

The male petasma also showed minor variations in its form between the two groups, with approximately $21 \%$ of Taiwanese specimens having a small but distinct spine-like projection at the base of the lobus ter- 
minalis as compared to less than $7 \%$ in the Japanese specimens (Fig. 6).

\section{Discussion}

Genetic diversity, as shown by haplotype diversity, was found to be very high in $S$. lucens. The values generated in this study are comparable with those derived from the mtDNA control region sequences for the crustaceans Farfantepenaeus aztecus (Ives, 1891), Litopenaeus setiferus (Linnaeus, 1767) and Panulirus penicillatus (Olivier, 1791) (McMillenJackson and Bert, 2003; Abdullah et al., in press). The reported value for haplotype diversity of penaeid shrimp and spiny lobster were 0.996 and 1.000 , respectively (Tzeng, 2007; Abdullah et al., in press), which is almost same to our study (ranging from 0.991 to 1.000$)$. The nucleotide diversity of penaeid shrimp (McMillen-Jackson and Bert, 2003) was higher than the value of $5.4 \%$ obtained in this study. A high level of genetic diversity in the mtDNA control region could be due to a large population size.

Omori et al. (1988) conducted a comparative genetic study of $S$. lucens for individuals collected from Suruga Bay, Japan and Tungkang waters, Taiwan, and found that the two populations differed in isoelectrophoretic patterns of water-soluble proteins, implying limited gene flow between them. The present study, based on the significance of isolation indicated by pairwise $F s t$ statistical analysis by AMOVA, also suggested a clear isolation between the Japanese and Taiwanese populations.

A similar disjunctive distribution has been observed in other crustaceans: i.e., Portunus trituberculatus (Miers, 1876) by Imai et al. (1999) and Imai and Numachi (2002), Farfantepenaeus aztecus by McMillen-Jackson and Bert (2003), Alpheus djeddensis (Coutiere, 1897) by Thompson et al. (2005), Parapenaeopsis hardwickii (Miers, 1878) by Tzeng (2007), and Uca arcuata by Aoki et al. (2008b). The Kuroshio Current runs along the eastern coasts of Taiwan and Japan at a rate of nearly 50 million $\mathrm{m}^{3} / \mathrm{s}$ (Taira, 1997; Ujiié et al., 2003). This strong northward current seemingly enhances the larval transportation. However, for some previously studied species (e.g., Uca arcuata, Sepioteuthis spp. and Siganus guttatus), no ongoing gene flow was found between the Japanese and Taiwanese populations (Aoki et al., 2008a, b; Imai and Aoki, 2012; Iwamoto et al., 2012). Additionally, the mtDNA data of this study clearly indi- cate a lack of ongoing gene flow in S. lucens. Although Omori et al. (1988) mentioned that Japanese and Taiwanese $S$. lucens were morphologically indistinguishable, in our examination minor but appreciable differences were found in the relative distance of photophores on the antennal scale. The shape of the petasma also slightly differed between the two populations as the males from Taiwan had a tendency to have a developed projection at the base of the lobus terminalis of the petasma (Fig. 6; Table 2).

Following these findings, we presume the isolation time between the Japanese and Taiwanese populations to be 305,000 years (middle of the Pleistocene) based on nucleotide divergence estimation time (19\%/ MY) for penaeid shrimps (Kimura, 1996; McMillenJackson and Bert, 2003). The edge of the Chinese continent, which carries several large rivers, was once much closer to the Okinawa Trough. Sergia lucens may require large rivers and ridges on the deep sea floor to sustain a large-sized population (Omori et al., 1988). Thus, it may be that there used to be several small populations along the continental shelf, among which gene flow most likely was maintained. However, now the main populations are distributed in central Japan and Taiwan at the edge of the continental shelf in isolation to each other.

The neutrality of mutations in the mtDNA control region was rejected on the basis of Tajima's $D$ and Fu and Li's $D$ tests. The significant negative values obtained using these tests suggest that the Japanese and Taiwanese populations have experienced a population expansion during their geographic history. The observed unimodal mismatched frequency distribution pattern also matched the predicted distribution under a model of population expansion. This unimodal pattern has also been observed in other crustaceans, including Euphausia superba Dana, 1850, F. aztecus, F. duorarum (Burkenroad, 1939), and $P$. hardwickii (see Zane et al., 1998; McMillen-Jackson and Bert, 2003; Tzeng, 2007).

Recently, Vereshchaka (2000) recorded a small number of S. lucens from off Borneo and New Guinea, which notably expanded the known geographical range of this species. Due to the disjunctive distribution of this species, coupled with the genetic differences observed in this study between the Japanese and Taiwanese populations, S. lucens is likely to be formed by several small breeding units implying high genetic variability. Further research into the relationships between these units is needed for effective conservation of this commercially important species. 


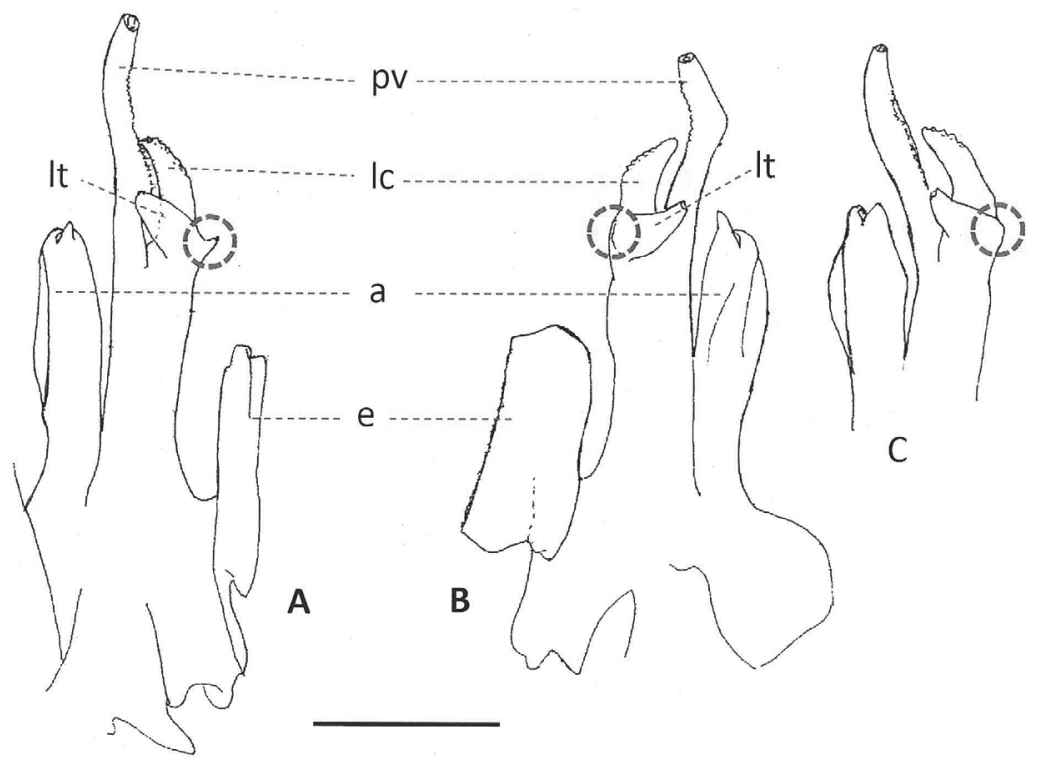

Fig. 6. Variation in form of petasma of Sergia lucens as indicated in the part of circle: male (10.3 mm in carapace length) from Suruga Bay, Japan, with no additional projection at the basal part of the lobus terminalis showing a typical from (entire part of left petasma, posterior view) (A); and male $(10.0 \mathrm{~mm})$ with a carinate swelling (distal part of right petasma, posterior view) (B); male from Taiwan $(10.3 \mathrm{~mm})$ with a distinct projection (entire part of right petasma, posterior view) (C): a, pars astringens; e, pars externa; lc, lobus terminals; lc. lobus connectens; $p v$, processus ventalis. Male with each form of petasma (A, B, C) was categorized as to III, I, and II in Table 2.

Table 1. Sampling locality, haplotype diversity (h), nucleotide diversity ( $\pi$ ), and Tajima's D and Fu and Li's D test results for the Japanese and Taiwanese populations. $* \mathrm{P}<0.005$.

\begin{tabular}{llllll}
\hline sample locality & sampling size & $\mathrm{h} \pm \mathrm{SD}$ & $\pi \pm \mathrm{SD}$ & Tajima's D & Fu and Li's D \\
\hline Suruga Bay, Japan & 70 & $0.991 \pm 0.01$ & $1.096 \pm 0.58$ & $-2.40^{*}$ & $-11.30^{*}$ \\
Gueishan waters, N Taiwan & 47 & $0.995 \pm 0.01$ & $1.331 \pm 0.70$ & $-2.03^{*}$ & $-2.38^{*}$ \\
Tungkang waters, S Taiwan & 61 & $1.000 \pm 0.00$ & $1.299 \pm 0.68$ & $-2.31^{*}$ & $-11.32^{*}$ \\
\hline
\end{tabular}

Table 2. Percentage occurrence of males with an additional projection at the base of the lobus terminals of the petasma. Basal part of lobus terminals (encircled part): I, smooth (typical form); II, carinate swelling; III, distinct projection.

\begin{tabular}{lll}
\hline category & Suruga Bay & Taiwan \\
\hline I & 50.0 & 39.4 \\
II & 43.7 & 39.4 \\
III & 6.3 & 21.2 \\
\hline total N & 16 & 33 \\
\hline
\end{tabular}

\section{Acknowledgements}

We thank the late Capt. Yoshiaki Ichikawa (No. 2 KyouseiMaru), Capt. Masanori Jitsuishi (Myoujin-Maru), Capt. Junichi Miyahara (Takayoshi-Maru), and Futoi-Maru of the "Sakura-ebi" Fisheries Cooperative Association for help in sampling at Suruga Bay; Prof. Shozo Sawamoto of Tokai University for providing some specimens from Suruga Bay; Director Dr. Tzyy-Ing Chen of the Taiwan Fisheries Research Insti- tute for help in sampling at the Tungkang fish market; Ms. Kaori Hirouchi for her assistance in preparing the manuscript and Mr. Abdullah Fadry Muhamad for his research assistance. We specially thank Asst. Prof. Tetsuo Yoshino of the University of the Ryukyus and Dr. Makoto Omori of the Akajima Marine Science Laboratory for some suggestions on species nomenclature. We also specially thank Asst. Prof. James Davis Reimer of the University of the Ryukyus for checking the manuscript's English. We thank two anonymous reviewers for their critical and editorial comments. This study was partially supported by a Grant-in-Aid for Young Scientists (B15780136) and the 21st Century COE program at the University of the Ryukyus from the Ministry of Education, Culture, Sports, Science and Technology, Japan.

\section{References}

Abdullah FM, Chow S, Sakai M, Cheng JH, Imai H. In press. Genetic diversity and population structure of pronghorn spiny lobster Panulirus penicillatus in the Pacific region. Pacific Science 68.

Aoki M, Imai H, Naruse T, Ikeda Y. 2008a. Low genetic diversity of oval squid Sepioteuthis cf. lessoniana (Cephalopoda: Loliginidae) in Japanese waters inferred from mitochondri- 
al DNA non-coding region. Pacific Science 62: 403-411.

Aoki M, Naruse T, Cheng JH, Suzuki S, Imai H. 2008b. Low genetic variability in an endangered population of fiddler crab Uca arcuata on Okinawajima Island: analysis of mitochondrial DNA. Fisheries Science 74: 330-340.

Bandelt HJ, Forster P, Rohl A. 1999. Median-joining networks for inferring intraspecific phylogenies. Molecular Biology and Evolution 16: 37-48.

Bishop GH, Omori M, Muranaka F. 1989. Temporal and spatial variations in the spawning activity of the micronektonic shrimp, Sergia lucens (Hansen) in Suruga Bay, Japan. Journal of the Oceanographical Society of Japan 45: 243-250.

Excoffier L, Smouse PE, Quattro JM. 1992. Analysis of molecular variance inferred from metric distance among DNA haplotypes: application to human mitochondrial DNA restriction data. Genetics 131: 479-491.

Excoffier L, Laval G, Schneider S. 2005. ARLEQUIN ver. 3.0: an integrated software package for population genetics data analysis. Evolutionary Bioinformatics Online 1: 47-50.

Fu YX, Li WH. 1993. Statistical tests of neutrality of mutations. Genetics 133: 693-709.

Fukui A, Hara T, Ito D, Hosho T, Uotani I. 2004. Abundance estimation of sergestid shrimp Sergia lucens in Suruga Bay. Nippon Suisan Gakkaishi 70: 592-597. (in Japanese, English abstract)

Gordon I. 1935. On new or imperfectly known species of Crustacea Macrura. Zoological Journal of the Linnean Society 39: 307-351.

Hansen HJ. 1922. Crustacés décapods (Sergestidae) provenant des Campagnes des yachts Hirondelle et Princesse-Alice (1885-1915). Résultats Campagnes Scientifiques accomplies sur son yacht par Albert Ier prince souverain de Monaco, 64: 20-39

Hirai K, Kitano T, Saitou M. 1992. Preliminary investigation on distribution and survival of eggs and early larvae (developmental stages) of sergestid shrimp, Sergia lucens (Hansen), in 1990. Bulletin of the Shizuoka Prefectural Fisheries Experiment Station 27: 1-7. (in Japanese)

Holthuis LB. 1980. FAO species catalogue: vol. 1 - shrimps and prawns of the world. FAO Fisheries Synopsis 125, Food and Agriculture Organization of the United Nations, Rome, Italy.

Hudson RR, Slantkin M, Maddison WP. 1992. Estimation of levels of gene flow from DNA sequence data. Genetics 132: 583-589.

Huzita S. 1959. Ecological investigation of Sergests lucens Hansen in Suruga Bay. Bulletin of the Educational Faculty, Shizuoka University 10: 235-244. (in Japanese, English summary).

ICZN (International Commission of Zoological Nomenclature) (2000): International code of zoological nomenclature, $4^{\text {th }}$ edition, adopted by the Union of Japanese Societies for Systematic Zoology. International Trust for Zoological Nomenclature, Hokkaido University, Sapporo, Japan (in Japanese).

Imai H, Aoki M. 2012. Genetic diversity and genetic heterogeneity of bigfin reef squid, "Sepioteuthis lessoniana" species complex in northwestern Pacific Ocean. Pp. 151-166 in: Caliskan M., ed., Analysis of Genetic Variation in Animals. Rijela: InTech.

Imai H, Numachi K. 2002. Genetic variability of swimming crab based on PCR-RFLP analysis of mitochondrial DNA D-loop region. Suisanzoshoku 50: 1-7. (in Japanese, English abstract)
Imai H, Fujii Y, Karakawa J, Yamamoto S, Numachi K. 1999. Analysis of the population structure of the swimming crab, Portunus trituberculatus in the coastal waters of Okayama Prefecture, by RFLPs in the whole region of mitochondrial DNA. Fisheries Science 65: 655-656.

Imai H, Cheng JH, Hamasaki K, Numachi K. 2004. Identification of four mud crab species (genus Scylla) using ITS-1 and 16S rDNA markers. Aquatic Living Resources 17: 31-34.

Isshiki T. 1996. Population density of the sergestid shrimp Sergia lucens in Tokyo Bay with special reference to predation by the blackthroat seaperch Doederleinia berycoides. Bulletin of the Kanagawa Prefectural Fisheries Research Institute 1: 21-25. (in Japanese, English abstract)

Isshiki T, Tajima Y. 1992. The research of a sergestid shrimp, Sergia lucens (Hansen) in the mouth of Tokyo Bay I. The seasonal distribution of adult and the distribution of eggs. Bulletin of the Kanagawa Prefectural Fisheries Experiment Station 13: 73-78 (in Japanese, English summary)

Iwamoto K, Chang C, Takemura A, Imai H. 2012. Genetically structured population and demographic history of the goldlined spinefoot Siganus guttatus in the northwestern Pacific. Fisheries Science 78: 249-257.

Kimura M. 1996. Quaternary paleogeography of the Ryukyu Arc. Journal of Geography 105: 259-285. (in Japanese, English abstract)

Kosaka M, Kubota T, Ogura M, Oda T, Nakai Z. 1969. Studies of the predatory species on the shrimp, Sergestes lucens in Suruga Bay. Journal of the College of Marine Science and Technology, Tokai University 3: 87-101. (in Japanese, English abstract)

Kubota T, Ikematsu M, Amano R. 1995. Bibliography on a sergestid shrimp (Sergia lucens) from Suruga Bay, central Japan (Further note). Bulletin of Institute of Oceanic Research and Development, Tokai University 16: 59-65. (in Japanese, English abstract)

Lee DA, Wu SH, Liao IC, Yu HP. 1996. On three species of commercially important sergestid shrimps (Decapoda: Sergestidae) in the coastal waters of Taiwan. Journal of Taiwan Fisheries Research 4: 1-19. (in Chinese, English abstract)

McMillen-Jackson AL, Bert TM. 2003. Disparate patterns of population genetic structure and population history in two sympatric penaeid shrimp species (Farfantepenaeus aztecus and Litopenaeus setiferus) in the eastern United States. Molecular Ecology 12: 2895-2905.

Minegishi Y, Aoyama J, Tsukamoto K. 2012. Lack of genetic heterogeneity in the Japanese eel based on a spatiotemporal sampling. Coastal Marine Science 35: 269-276.

Muranaka F, Jo SG. 1990. Small-scale distribution of eggs and early larvae of sergestid shrimp, Sergia lucens (Hansen), at the main spawning ground in Suruga Bay. Bulletin of the Shizuoka Prefectural Fisheries Experiment Station 25: 1-9. (in Japanese)

Nakazawa K. 1932. On three species of genus Sergestes found in Suruga Bay. Zoological Magazine, Tokyo 44: 31-32. (in Japanese)

Nakazawa K, Terao A. 1915. Studies on sakura shrimp. Zoological Magazine, Tokyo 27: 622-630. (in Japanese)

Nei M. 1987. Molecular evolutionary genetics. New York: Columbia University Press. 
Omori M. 1969. The biology of a sergestid shrimp Sergestes lucens Hansen. Bulletin of the Ocean Research Institute, University of Tokyo 4: 1-83.

Omori M. 1971. Preliminary rearing experiments on the larvae of Sergestes lucens (Penaeidae, Natantia, Decapoda). Marine Biology 9: 228-234.

Omori M. 1989. Fishery of a sergestid shrimp Sergia lucens (Hansen) at Tung-kang, Taiwan. Bulletin of the Japanese Society of Fisheries Oceanography 53: 108-110. (in Japanese)

Omori M. 1995. Biology of sakura shrimp. "Sakura-ebi”-History of one hundred years of the sergestid shrimp fishing industry. Pp. 64-74 in: Omori M and Shida K, eds. Shizuoka: Shizuoka Shinbunsha. (in Japanese)

Omori M, Ohta S. 1981. The use of underwater camera in studies of vertical distribution and swimming behavior of a sergestid shrimp Sergia lucens. Journal of Plankton Research 3: 107-121.

Omori M, Seino Y. 1993. Feeding reference of the hairtail Trichilurus lepturus Linnaeus in and neighboring the waters where Sergia lucens swarms in Suruga Bay. Bulletin of the Japanese Society of Fisheries Oceanography 57: 15-23. (in Japanese, English abstract)

Omori M, Ukishima Y, Muranaka F. 1988. New record of occurrence of Sergia lucens (Hansen) (Crustacea, Sergestidae) off Tung-kang, Taiwan, with special reference to phylogeny and distribution of the species. Journal of the Oceanographical Society of Japan 44: 261-267. (in Japanese, English abstract)

Raymond M, Roussett F. 1995. Genepop (Ver.1.2): population genetics software for exact tests and ecumenicism. Journal of Heredity 86: 248-249.

Reynolds J, Weir BS, Cockerham CC. 1983. Estimation for the coancestry coefficient: basis for a short-term genetic distance. Genetics 105: 767-779.

Rice WR. 1989. Analyzing tables of statistical tests. Evolution 43: 223-225.

Taira K. 1997. Sea as a fluid. Pp. 61-87 in: The Ocean Research Institute, University of Tokyo eds, System of ocean. Nippon Jitsugyo Publishing, Tokyo. (in Japanese)

Tajima F. 1983. Evolutionary relationship of DNA sequences in finite populations. Genetics 105: 437-460.
Tajima F. 1989. Statistical method for testing the neutral mutation hypothesis by DNA polymorphism. Genetics 123 : 585-595.

Taniguchi N, Numachi K. 1978. Genetic variation of 6-phosphogluconate dehydrogenase, isocitrate dehydrogenase, and glutamic-oxaloacetic transaminase in the liver of Japanese eel. Bulletin of the Japanese Society of Scientific Fisheries 44: 1351-1355.

Thompson JD, Gibson TJ, Plewniak F, Jeanmougin F, Higgins DG. 1997. The CLUSTAL-X windows interface: flexible strategies for multiple sequence alignment aided by quality analysis tools. Nucleic Acids Research 25: 4876-4882.

Thompson AR, Thacker CE, Shaw E. 2005. Phylogeography of marine mutualists: parallel patterns of genetic structure between obligate goby and shrimp partners. Molecular Ecology 14: 3557-3572.

Tsukui F. 1987. Relationship between reproduction of a sergestid shrimp Sergia lucens (Hansen) and water temperature during the spawning season. Bulletin of the Shizuoka Prefectural Fisheries Experiment Station 22: 1-11. (in Japanese)

Tzeng TD. 2007. Population structure of the sword prawn (Parapenaeopsis hardwickii) (Decapoda: Penaeidae) in the East China Sea and waters adjacent to Taiwan inferred from the mitochondrial control region. Zoological Studies 46: 561-568.

Ujiié Y, Ujiié H, Taira A, Nakamura T, Oguri K. 2003. Spatial and temporal variability of surface water in the Kuroshio source region, Pacific Ocean, over the past 21,000 years: evidence from planktonic foraminifera. Marine and Micropaleontology 49: 335-364.

Vereshchaka AL. 2000. Revision of the genus Sergia (Decapoda: Dendrobranchiata: Sergestidae): taxonomy and distribution. Galathea Report 18: 69-207.

Zane L, Ostellari L, Maccatrozzo L, Bargelloni L, Battaglia B, Patarnello T. 1998. Molecular evidence for genetic subdivision of Antarctic krill (Euphausia superba Dana) populations. Proceeding of the Royal Society of London B 265: 2387-2391.

Received: 23 November 2012

Revised and accepted: 9 August 2013

Published online: 27 September 2013

Editor: R. Vonk

\section{On-line Supplementary Information (SI)}

S1. Variable sites in the 162 haplotypes found in mtDNA control region of 178 Sergia lucens. The numbers above sequences correspond to the positions of the polymorphic sites. Dots indicate an identical nucleotide at the position relative to haplotype 1 . 


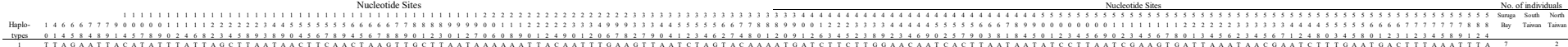

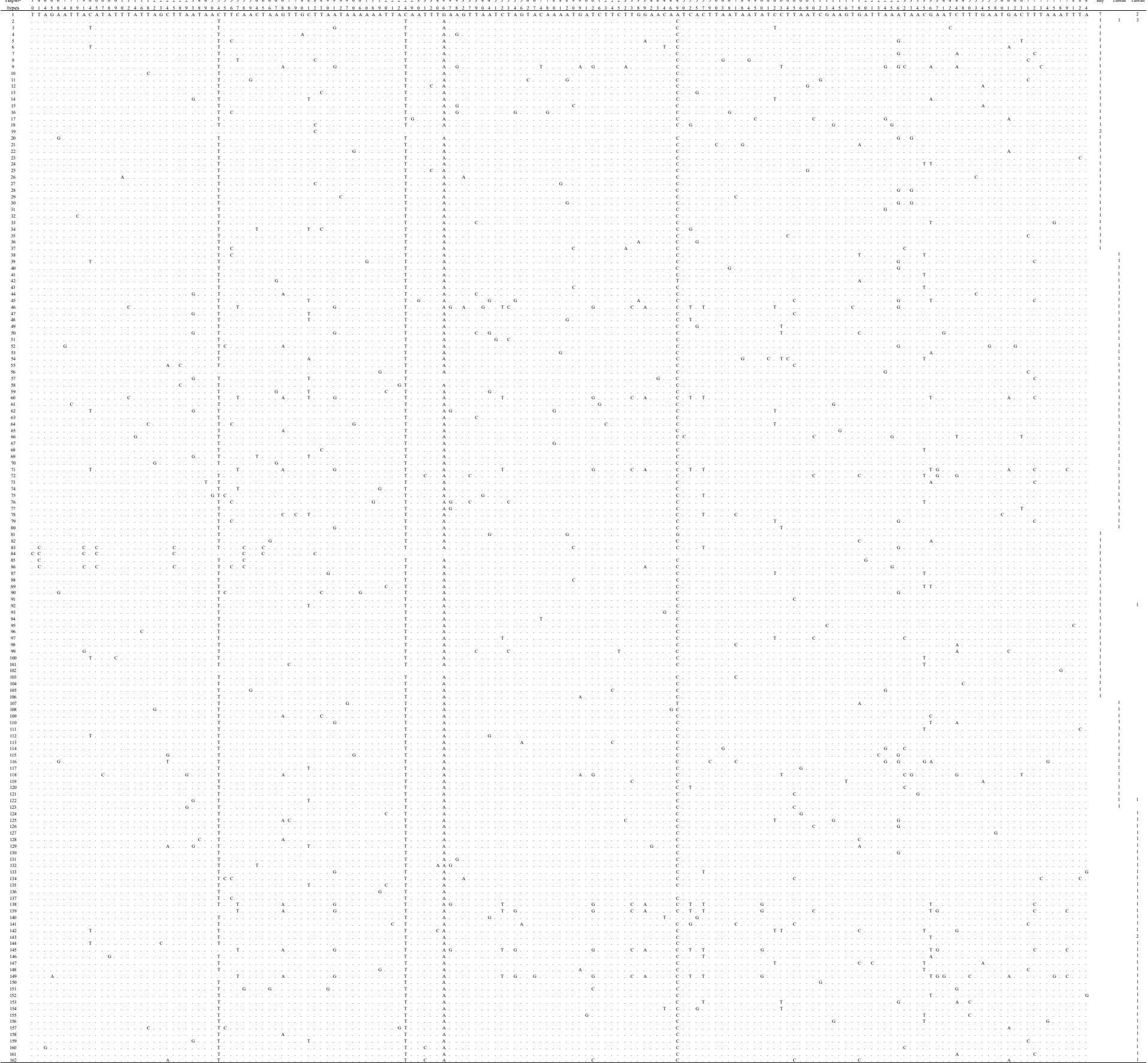

